\title{
Effect of Salinity on Growth of Different Mungbean Varieties
}

\author{
Muhammad Arshad Ullah ${ }^{1}$, Raheel Baber ${ }^{1}$, Syed Ishtiaq Hyder ${ }^{1}$, Imdad Ali Mahmood ${ }^{1}$, \\ Muhammad Tauqir ${ }^{2}$ \\ ${ }^{1}$ National Agricultural Research centre, Islamabad. Pakistan. \\ ${ }^{2}$ Faculty of Agriculture, Gomal University, Dera Ismail Khan, KPK, Pakistan
}

\begin{abstract}
Seeds of mungbean varieties i.e. NCM-2013, Chackwal-Mung 06, NM-11 and AZRI-06 were selected for screening in saline soil. These miunngbean varieties were sown with normal as well as artificially salinity developed soil $\left(E C e=5.0 \mathrm{dSm}^{-1}\right)$ using completely randomized design with three repeats for screening purposes. The experiment was conducted during July to September, 2015 in the Head House of Land Resources Research Institute, National Agricultural research Centre, Islamabad, Pakistan. Data were collected on germination, plant height, root length, fresh / dry weight and chlorophyll contents during experiment period. Ionic concentrations of $\mathrm{P}, \mathrm{Cu}, \mathrm{Fe}, \mathrm{Mg}$ and $\mathrm{Zn}$ were determined to compare the difference of edible quality in normal soil as well as saline soil Agronomic parameters like germination\%, shoot height, root length, fresh weight/plant, dry weight/plant and chlorophyll content\% were significantly affected by mungbean varieties under normal and saline conditions for screening purpose. Maximum germination (65\% and 40\%) was recorded under normal and saline soils $r$ by NM-II and AZRI-06 mungbean varieties respectively. Shoot length was maximum $(31.5 \mathrm{~cm}$ and $12.5 \mathrm{~cm})$ by AZRI-06 and NM-II under normal and saline soil conditions respectively. Whereby root showed maximum lengths $(16.5 \mathrm{~cm}$ and $6.3 \mathrm{~cm})$ by AZRI-06 and NM-II respectively. Fresh weight were the highest (7.6 $\mathrm{g}$ and $3.45 \mathrm{~g}$ ) by AZRI-06 under both conditions. Dry weight was concerned it was the maximum (1.4 $\mathrm{g}$ and $0.6 \mathrm{~g})$ by AZRI-06 and NCM-2013 under normal and saline conditions respectively. Maximum chlorophyll contents (34.6\% and $25.1 \%)$ were registered by AZRI-O6 and NM-II under normal and saline conditions respectively. Maximum P\% (0.13), Cu (5.01ppm), Fe (177.1ppm), Mg (1.99ppm) and $\mathrm{Zn}$ (158.8ppm) of Chakwal Mung-06 in normal soil and similar trend was also recorded in ionic concentration of $\mathrm{P}, \mathrm{Cu}, \mathrm{Fe}$ and $\mathrm{Mg}$ under saline soil. The saline soil affected the quality of mungbean showing the reduction under salt stress in ionic concentration. The results of ionic values showed that Chakwal Mung-06 attained the highest position following the AZRI-06.
\end{abstract}

Keywords: Mungbean varieties, saline soil, growth, ediblee quality and ionic concentration

\section{INTRODUCTION}

Mungbean is a very important pulse crop which provides an inexpensive source of vegetable dietary protein. In Pakistan, mungbean is cultivated on an area of 127.7 thousand hectares with total grain production of 98.7 thousand tons Economic survey of Pakistan, 15). It is popular for its nutritive value and digestibility, containing higher protein contents $(30 \%)$, fat $(1.2 \%)$, carbohydrates $(65 \%)$ and essential macronutrients like Phosphorus $340 \mathrm{mg} 100 \mathrm{~g}^{-1}$ and Calcium $118 \mathrm{mg} 100 \mathrm{~g}^{-1}$ (Anwar et al., 2007). It can be cultivated during spring and winter and takes less time to mature and fits well in existing cropping pattern of the country. Today, of various abiotic stresses, soil salinity is known to cause considerable crop losses (Ashraf et al., 2008). Although soil salinity occurs predominantly in arid and semiarid regions, it has been found in all the climatic zones (Munns, 2008). Moreover, the problem in salt affected land is increasing due to low quality water usage for irrigation, improper drainage in canal-irrigated wetland agro-ecosystems, entry of seawater in coastal areas during cyclones, and higher accumulation of salts in the root zone due to considerable evaporation of water and insufficient leaching of ions due to low rainfall in arid and semi-arid regions (Munns, 2008). According to an estimate, $33 \%$ of irrigated land world-wide has been affected by salinity (Ashraf et al., 2008). Pakistan is worst hit by soil salinity as about $14 \%$ of total irrigated land in Pakistan is salt affected (Economic Survey of Pakistan, 2008). Salt affected soils are generally categorized as saline, sodic, or saline-sodic. In other words, a soil is considered to be saline when electrical conductivity of saturate soil pastes is equal or greater than $4 \mathrm{dS} \mathrm{m}^{-1}$ at $25^{\circ} \mathrm{C}$ (equivalent to $40 \mathrm{mM} \mathrm{NaCl}$ ) and the sodium adsorption ratio (SAR) is 13-15 (Munns, 2008). 
Inside the plant, soluble salts at higher concentrations cause hyperosmolality, ion toxicity and disequilibrium of nutrients that adversely affect plant growth and development (Munns, 2008). High levels of both $\mathrm{Na}+$ and $\mathrm{Cl}$ - in cytosol are inhibitory to a number of metabolic and cellular processes (Ashraf, 2009).

Soil salinity causes prominent losses of yield in all crops, therefore causing to reduction in crop production (Ashraf,. 2009 and Cha-um. et al., 2011). Reduction in yield due to salinity is due to a number of physiological and biochemical abnormalities in plants grown which have been mentioned in a number of comprehensive reviews on salinity effects and tolerance in plants (Ashraf et al., 2008, Munns , 2008, Jamil et al., .2011,and Krasensky and Jonak,. 2012). Researchers have been struggling for the last many decades to solve this issue by conducting a variety of experiments. The conductance of such experiments has resulted in a substantial increase in both growth and yield of many crops grown under saline conditions (Ashraf,. 2009 and Cha-um. et al., 2011) Exogenous application of inorganic essential nutrients as foliar spray or through the root growing medium has also been reported to be an economical and efficient means of mitigating the adverse effects of salt stress on different crops (Ashraf,. 2009 and Kaya et al., 2010) of different major essential nutrients, potassium (K) and phosphorus (P) play vital roles in plant growth and regulate various metabolic reactions( Taiz and Zeiger, 2010).. Therefore this study was carried out to evaluate the performance of mungbean varieties under saline condition for the enhancement of pulse production under marginal lands.

\section{Materials AND Methods}

Seeds of mungbean varieties i.e. NCM-2013, Chackwal-Mung 06, NM-11 and AZRI-06 were selected for screening in saline soil. These miunngbean varieties were sown with normal as well as artificially salinity developed soil $\left(\mathrm{ECe}=5.0 \mathrm{dSm}^{-1}\right)$ using completely randomized design with three repeats for screening purposes. The experiment was conducted during July to September, 2015 in the Head House of Land Resources Research Institute, National Agricultural research Centre, Islamabad, Pakistan. Data were collected on germination, plant height, root length, fresh / dry weight and chlorophyll contents during experiment period. Ionic concentrations of $\mathrm{P}, \mathrm{Cu}, \mathrm{Fe}, \mathrm{Mg}$ and $\mathrm{Zn}$ were determined to compare the difference of edible quality in normal soil as well as saline soil. The data collected were analyzed statistically according to the procedure given using statistic, 2000 package and means between treatments were compared using LSD test at 5\% probability level (Steel and Torrie, 1997)

\section{RESUltS AND DisCUSSION}

Agronomic parameter like germination\%, shoot height, root length, fresh weight/plant, dry weight/plant and chlorophyll content $\%$ were significantly affected by mungbean varieties under normal and saline conditions for screening purpose as mentioned in table1.Maximum germination (65\% and 40\%) was recorded under normal and saline soils $\mathrm{r}$ by NM-II and AZRI-06 mungbean varieties respectively. Shoot length was maximum $(31.5 \mathrm{~cm}$ and $12.5 \mathrm{~cm})$ by AZRI-06 and NM-11 under normal and saline soil conditions respectively. Whereby root showed maximum lengths $(16.5 \mathrm{~cm}$ and $6.3 \mathrm{~cm})$ by AZRI-06 and NM-II respectively. Fresh weight were the highest $(7.6 \mathrm{~g}$ and $3.45 \mathrm{~g})$ by AZRI-06 under both conditions. Dry weight was concerned it was the maximum (1.4 $\mathrm{g}$ and $0.6 \mathrm{~g})$ by AZRI-06 and NCM-2013 under normal and saline conditions respectively. Maximum chlorophyll contents (34.6\% and $25.1 \%$ ) were registered by AZRI-06 and NM-11under normal and saline conditions respectively. These results are agreed with the findings of (Ashraf et al., 2008, Munns , 2008, Jamil et al., .2011, and Krasensky and Jonak,. 2012).

Maximum P\% (0.13), Cu (5.01ppm), Fe (177.1ppm), Mg (1.99ppm) and $\mathrm{Zn}$ (158.8ppm) of Chakwal Mung-06 in normal soil and similar trend was also recorded in ionic concentration of $\mathrm{P}, \mathrm{Cu}, \mathrm{Fe}$ and $\mathrm{Mg}$ under saline soil Table-2). The saline soil affected the quality of mungbean showing the reduction under salt stress in ionic concentration. The results of ionic values showed that chakwal Mung-06 attained the highest position following the AZRI-06. (Ashraf et al., 2008 Akram et al.,. 2009 and Taiz and Zeigr,2010 ) reported same results regarding $\mathrm{K}$ and $\mathrm{P}$ of different crops under salt stress conditions. 
Table1. Effect of salinity on germination, plant height, root length, fresh / dry weight and chlorophyll contents of Mungbean varieties

\begin{tabular}{|c|c|c|c|c|c|c|c|c|c|c|c|c|}
\hline \multirow{2}{*}{$\begin{array}{l}\text { Mung bean } \\
\text { Varieties }\end{array}$} & \multicolumn{2}{|c|}{$\begin{array}{l}\text { Germination } \\
(\%)\end{array}$} & \multicolumn{2}{|c|}{$\begin{array}{l}\text { Shoot height } \\
(\mathrm{cm})\end{array}$} & \multicolumn{2}{|c|}{$\begin{array}{l}\text { Root length } \\
(\mathrm{cm})\end{array}$} & \multicolumn{2}{|c|}{$\begin{array}{l}\text { Fresh weight } \\
\text { plant }^{-1}(\mathrm{gm})\end{array}$} & \multicolumn{2}{|c|}{$\begin{array}{l}\text { Dry weight } \\
\text { plant }^{-1}(\mathrm{gm})\end{array}$} & \multicolumn{2}{|c|}{$\begin{array}{l}\text { Chlorophyll } \\
\text { Contents (\%) }\end{array}$} \\
\hline & $\begin{array}{l}\text { Normal } \\
\text { soil }\end{array}$ & $\begin{array}{l}\text { Saline } \\
\text { soil }\end{array}$ & $\begin{array}{l}\text { Normal } \\
\text { soil }\end{array}$ & $\begin{array}{l}\text { Saline } \\
\text { soil }\end{array}$ & $\begin{array}{l}\text { Normal } \\
\text { soil }\end{array}$ & $\begin{array}{l}\text { Saline } \\
\text { soil }\end{array}$ & $\begin{array}{l}\text { Normal } \\
\text { soil }\end{array}$ & $\begin{array}{l}\text { Saline } \\
\text { soil }\end{array}$ & $\begin{array}{l}\text { Normal } \\
\text { soil }\end{array}$ & $\begin{array}{l}\text { Saline } \\
\text { soil }\end{array}$ & $\begin{array}{l}\text { Normal } \\
\text { soil }\end{array}$ & $\begin{array}{l}\text { Saline } \\
\text { soil }\end{array}$ \\
\hline NCM-2013 & $60 a$ & $30 b c$ & $29 a$ & $11.1 \mathrm{~d}$ & $11.3 \mathrm{~b}$ & $6.1 \mathrm{~cd}$ & $7.4 \mathrm{a}$ & $3.17 \mathrm{c}$ & $1.2 \mathrm{a}$ & $0.6 \mathrm{ab}$ & $30.3 \mathrm{a}$ & $24.8 \mathrm{c}$ \\
\hline $\begin{array}{l}\text { Chackwal- } \\
\text { Mung } \\
06 \\
\end{array}$ & $60 a$ & $35 b$ & $20.8 b c$ & $7.2 \mathrm{f}$ & $11.0 \mathrm{~b}$ & $5.2 \mathrm{de}$ & $7.1 \mathrm{a}$ & $3.07 \mathrm{c}$ & $1.2 \mathrm{a}$ & $0.6 \mathrm{ab}$ & $29.1 b$ & $22.9 c$ \\
\hline NM-11 & $65 a$ & $30 b c$ & $25.8 b$ & $e^{12.5 d}$ & $16.2 \mathrm{a}$ & $6.3 \mathrm{~cd}$ & $6.3 \mathrm{~b}$ & $2.99 \mathrm{~cd}$ & $1.2 \mathrm{a}$ & $0.4 \mathrm{~b}$ & $34.3 \mathrm{a}$ & $25.1 \mathrm{bc}$ \\
\hline AZRI-06 & $60 a$ & $40 \mathrm{~b}$ & $31.5 \mathrm{a}$ & $10.7 \mathrm{ef}$ & $16.5 \mathrm{a}$ & $5.2 \mathrm{de}$ & $7.6 \mathrm{a}$ & $3.45 b c$ & $1.4 \mathrm{a}$ & $0.3 b c$ & $34.6 \mathrm{a}$ & $23.2 \mathrm{c}$ \\
\hline LSD & 20 & & 5.9 & & 4.4 & & 1.4 & & 0.7 & & 4.2 & \\
\hline
\end{tabular}

Table2. Effect of Salinity on ionic concentration of $\mathrm{P}, \mathrm{Cu}, \mathrm{Fe}, \mathrm{Mg}$ and $\mathrm{Zn}$ of Mungbean varieties

\begin{tabular}{|c|c|c|c|c|c|c|c|c|c|c|}
\hline \multirow{2}{*}{$\begin{array}{l}\text { Mung bean } \\
\text { Varieties }\end{array}$} & \multicolumn{2}{|l|}{$\begin{array}{l}\mathrm{P} \\
(\%)\end{array}$} & \multicolumn{2}{|l|}{$\begin{array}{l}\mathrm{Cu} \\
(\mathrm{ppm})\end{array}$} & \multicolumn{2}{|l|}{$\begin{array}{l}\mathrm{Fe} \\
(\mathrm{ppm})\end{array}$} & \multicolumn{2}{|l|}{$\begin{array}{l}\mathrm{Mg} \\
(\mathrm{ppm})\end{array}$} & \multicolumn{2}{|l|}{$\begin{array}{l}\mathrm{Zn} \\
(\mathrm{ppm})\end{array}$} \\
\hline & $\begin{array}{l}\text { Normal } \\
\text { soil }\end{array}$ & $\begin{array}{l}\text { Saline } \\
\text { soil }\end{array}$ & $\begin{array}{l}\text { Normal } \\
\text { soil }\end{array}$ & $\begin{array}{l}\text { Saline } \\
\text { soil }\end{array}$ & $\begin{array}{l}\text { Normal } \\
\text { soil }\end{array}$ & $\begin{array}{l}\text { Saline } \\
\text { soil }\end{array}$ & $\begin{array}{l}\begin{array}{l}\text { Normal } \\
\text { soil }\end{array} \\
\end{array}$ & $\begin{array}{l}\text { Saline } \\
\text { soil }\end{array}$ & $\begin{array}{l}\text { Normal } \\
\text { soil }\end{array}$ & $\begin{array}{l}\text { Saline } \\
\text { soil }\end{array}$ \\
\hline NCM-2013 & 0.08 & 0.04 & 4.62 & 2.12 & 176.4 & 140.3 & 1.82 & 1.72 & 152.7 & 100.4 \\
\hline $\begin{array}{l}\text { Chackwal- } \\
\text { Mung } \\
06\end{array}$ & 0.13 & 0.06 & 5.01 & 2.83 & 177.1 & 142.4 & 1.99 & 1.85 & 158.8 & 105.6 \\
\hline NM-11 & 0.08 & 0.04 & 4.26 & 1.94 & 162.4 & 139.3 & 1.62 & 1.25 & 142.3 & 99.8 \\
\hline AZRI-06 & 0.09 & 0.06 & 4.33 & 1.98 & 165.6 & 140.2 & 1.47 & 1.78 & 155.4 & 103.1 \\
\hline
\end{tabular}

\section{CONCLUSION AND RECOMMENDATION}

Among four mungbean varieties Chakwal Mung-06 performed well in normal as well as saline soil. Chakwal Mung-06 will be further evaluated using biozote under salt stress conditions.

\section{REFERENCES}

Akram MS, Ashraf M and Akram NA. 2009. Effectiveness of potassium sulfate in mitigating saltinduced adverse effects on different physio-biochemical attributes in sunflower (Helianthus annuus L.). Flora 204: 471-483

Anwar, F., S. Latif, R. Przybylski, B. Sultana and M. Ashraf. 2007. Chemical composition and antioxidant activity of seeds of different cultivars of mungbean. J. Food Sci., 72(7): 503-510.

Ashraf M. 2009. Biotechnological approach of improving plant salt tolerance using antioxidants as markers. Biotech Adv. 27: 84-93

Ashraf M, Athar HR, Harris PJC and Kwon TR. 2008. Some prospective strategies for improving crop salt tolerance. Adv Agron . 97: 45-110].

Cha-um S, Pokasombat Y and Kirdmanee C. 2011. Remediation of salt-affected soil by gypsum and farmyard manure - Importance for the production of Jasmine rice. Aust J Crop Sci. 5: 458-465.

Economic Survey of Pakistan, 2008.Government of Pakistan.p.145.

Economic Survey of Pakistan, 2015...Government of Pakistan.p.222.

Jamil A, Riaz S, Ashraf M and Foolad MR. 2011. Gene expression profiling of plants under salt stress. Crit Rev Plant Sci 30: 435-458

Kaya C, Tuna AL and Okant AM. 2010. Effect of foliar applied kinetin and indole acetic acid on maize plants grown under saline conditions. Turk J Agr For 34: 529-538.

Krasensky J and Jonak C. 2012. Drought, salt, and temperature stress-induced metabolic rearrangements and regulatory networks. J Exp Bot. 63: 1593-1608

Munns R, Tester M 2008. Mechanisms of salinity tolerance. Annu Rev Plant Biol., 59: 651-681

Steel, R.G.D. and J.H. Torrie,, 1997. Principles and Procedure of Statistics. McGraw Hill Book Co., Inc. Singapore, pp: 173-177.

Taiz L and Zeiger E. 2010. Plant Physiology, Sinecure Associates, Inc. Publishers, Sunderland, Massachusetts, p.782. 